\title{
Volumetric estimation of an intensive apple orchard with GIS
}

\author{
Riczu, P. ${ }^{1}$, Bozsik É. ${ }^{1}$, Gálya B. ${ }^{1}$, Rásó J. ${ }^{2}$, Csiha I. ${ }^{2}$, El Shal, A. M. ${ }^{3}$, Nyéki J. ${ }^{4}$ \& Tamás J. ${ }^{1}$ \\ ${ }^{1}$ University of Debrecen, Institute of Water and Environmental Management, \\ Debrecen, 4032 Böszörményi str. 138. \\ ${ }^{2}$ National Agricultural and Innovation Centre, Forest Research Institute, Experimental Station of Püspökladány, \\ 4150 Püspökladány, Farkassziget 3. \\ ${ }^{3}$ Zagazig University, Faculty of Agriculture, Department of Agricultural Engineering, 44511 Zagazig, Egypt \\ ${ }^{4}$ University of Debrecen, Institute of Horticulture, 4032 Debrecen, Böszörményi str. 138. \\ riczu@agr.unideb.hu
}

\begin{abstract}
Summary: Remote sensing instruments and methods have become widespread in all segments of agriculture and horticulture. Among the innovative development of remote sensing instruments, the 3D laser scanner is one of the newest technique, which overtop in the spatial data collection. Terrestrial laser scanning is an appropriate tool for identifying such biophysical parameters like the structure of trees and branches, growth of volume. Determination of these parameters are time consuming and complicated with traditional methods. The examination was carried out in the Study and Regional Research Farm of the University of Debrecen near Pallag. We used Leica ScanStation C10 terrestrial laser scanner to estimate volumetric properties of the intensive apple orchard. Two rows of the study area were surveyed, where the height and stem diameter of apple trees were measured with Geomagic Studio 12 GIS Demo Software. Based on the built-in algorithms, the volume of each tree were defined by the software. The measured and calculated data was correlated, and middle correlations were detected. Estimated volume results could be useful for further investigation such as $\mathrm{CO}_{2}$ fixing, which is an important factor for ecological service of the plantation.
\end{abstract}

Key words: intensive apple orchard, laser scanning, timber

\section{Introduction}

The Earth's ecosystems provides to a wide range of benefits to humanity known as "ecosystem services." This has given the present balance of human resource usage increasing attention is being paid in almost every area of science. The UN initiative created by the Millennium Ecosystem Assessment in 2003, which discusses in detail the current and future status of individual ecosystems. In this announcement, the experts have been identified in four different types of services, which are listed below:

- the supply provisioning services (such as water, timber, fiber, etc.)

- the regulating services (e.g. climate, rainfall, flood control, disease control, etc.)

- cultural services (such as the cultural, recreational, and cultural benefits, etc.)

- supporting services (such as photosynthesis, nutrient cycling, soil formation)

The green areas are known to plays a decisive role in the proper functioning of terrestrial ecosystems. The vegetation primary service is the production of oxygen, $\mathrm{CO}_{2}$ absorption and fixation, thereby contributing to the reduction of the greenhouse effect (Gyeviki et.al., 2011). Trees have got the largest carbon sink potential in the ecosystem types. The reduction of forests at the global level (e.g. deforestation, forest fires, natural decay, etc.). Nevertheless, international actions were appearance, which reduce greenhouse gases. Thus, it became necessary to elaborate forest carbon sink capacity estimations. In our country, Führer and Járó (1989) and Führer et al., (1991) dealt first with the estimates the magnitude and variance of the forest carbon stock. The role of vegetation is highly depends on some vegetation indices which correlate to the biomass, species and variety composition, spatial location, the leaf surface and volume of tree (Radó, 2001). The estimation of assimilated $\mathrm{CO}_{2}$ fixation in an orchard is especially necessary to define the volume of trees, because during the assimilation, the amount of absorbed and incorporated carbon dioxide appear in the plant biomass production (Kiss et al., 2011). Although, fruit orchards are artificial ecosystems, but they represent a significant biologically active green mass in the environment 
ecosystems. Gyeviki et al., (2012) examined and evaluated the active green mass, in the context of $\mathrm{CO}_{2}$ fixation and water use of a cherry plantation. They examined the leaf surface temperature, stoma conductivity and photosynthetic activity of fruit trees.

In our investigation, to estimate timber volume, a special 3D remote sensing instrument and GIS software were used. Remote sensing, also called earth observation, refers to obtaining information about objects or areas at the Earth's surface without being in direct physical contact with the object or area (Belényesi et al., 2008). Remote sensing provides to get information from large areas beside/instead of traditional sampling data (Burai, 2007). According to Lóki (1996) the remote sensing means not only a special data collection, but processing and evaluation of these data also. The principle of remote sensing based on interactions and investigations of electromagnetic radiation with material (e.g. earth's surface). The basis of remote sensing is incoming radiation to the object $\left(\mathrm{E}_{\mathrm{I}}\right)$. When the radiation incident upon the object's surface, is either reflected $\left(E_{R}\right)$ by the surface, transmitted $\left(\mathrm{E}_{\mathrm{T}}\right)$ into the surface or absorbed $\left(\mathrm{E}_{\mathrm{A}}\right)$ and emitted by the surface. These variables are depending by the wavelength $(\lambda)$. So, it could be created the following equation:

$$
E_{R}(\lambda)+E_{A}(\lambda)+E_{T}(\lambda)=E_{I}(\lambda)
$$

It could be determined from the equation that on given wavelength the reflection, absorption and transmission are equal to the total incoming radiation. The values are always depended on the physical characteristics of the object and the geometric structure. When a remote sensing instrument has a line-of-sight with an object that is reflecting solar energy, then the instrument collects that reflected energy and records the observation. Most remote sensing systems are designed to collect reflected radiation (Short, 2011). Based on the measured values it could be concluded to physical and possibly chemical characteristic of the observed object (Molenaar, 1993). There are two types of remote sensing: passive remote sensing and active remote sensing. Passive remote sensing is detected natural radiation that is reflected by the object or surrounding area being observed. Reflected sunlight is the most common source of radiation measured by passive sensors (Belényesi et al., 2008). One of the newest and extremely developed spatial data collection techniques are the LiDAR (Light Detection And Ranging) technique (Heritage and Large 2009). Laser scanner analyze the real world by a laser beam and collect surface information about the object. Based on the reflected part of the laser beam, a high density so-called point cloud is creating by the scanner, which is a high quality $3 \mathrm{D}$ representation of the object's geometry. The first laser scanners were used in forestry, which has a wide range of rather complex 3D modelling tasks in field such as forest management, tree modeling, habitat examinations and carbon sink analysis as well (Vosselman and Hans-Gerd 2010).

There are researches, where positions and typical parameters (such as foliage structure, trunk diameter, tree height, etc.) of fruit trees can be successful determined by the 3D laser scanner remote sensing (Huang and Pretzsch 2010; Seidel et al., 2011). Stephens et al., (2007) report investigations to confirm the relationship between LiDAR variables and forest carbon, height, basal area and age at plot scale. Carbon in artificial orchard by laser scanning technologies are less studied.

We examined in present investigation the software background of point cloud processing and it was defined the correlations of some parameters by the laser scanner.

\section{Material and methods}

In our research the plot area was an intensive apple orchard with drip irrigation system, protected by hail net in Regional Research Farm of the University of Debrecen near Pallag. The ScanStation C10 by Leica Geosystems based on the time-of-flight (TOF) principle for ranging. A short laser pulse is emitted towards the object and is reflected on its surface and a part of the reflected radiation comes back to the scanner where it is detected by a sensor.

The high scan rate of up to 50,000 points/sec which provides the fast determination of objects. The laser beam is emitted in the green wavelength range at $532 \mathrm{~nm}$ wavelength. The green laser light scans the objects; the deflection of laser beam is occurred by a Smart X-Mirror ${ }^{\mathrm{TM}}$ automatically spins polygon mirror system. Thus the scanner creates a point cloud with high speed. The maximum range- which depends on the albedo- of laser scanner is $300 \mathrm{~m}$. The beam divergence is $0.1 \mathrm{mrad}$, so it means that the diameter of laser point is 10 $\mathrm{mm}$ on $100 \mathrm{~m}$. This value is only $3 \mathrm{~cm}$ in case of maximal measurement distance. The horizontal viewing angle of laser scanner is $360^{\circ}$ and vertical is $270^{\circ}$. The integrated 4 megapixel (1920x1920 pixel) camera takes photos to color the point cloud. The Field-of-View of the camera is $17^{\circ}$, so the automatically spatially rectified (panoramic) dome was made form 260 images on each scan position.

We have measured two rows (92 apple trees) of study plantation with 8 scan stations in leafless condition. The overlapping of scanning areas provided the joining of point clouds, and increased the accuracy of measurement. The scan resolution was $8 \mathrm{~mm}$ on $10 \mathrm{~m}$, so the accuracy was below $1 \mathrm{~cm}$ on the right side. The processing of raw point cloud was carried out by Leica Cyclone 7.1 software than for post processing, Geomagic Studio 12 Software was used. The Leica Cyclone was ideal for registering the 8 scan stations and export the point clod for further data mining. Cleaning the point cloud form noises (disconnected points and components) the Geomagic Studio 12 software was more effective. After the noise reduction, an automatically triangulation was used to create the volume of trees. This operation is robust, since Delaunay triangulation method determines the number of created triangles. Considering the - Due to the branches, data losing was happened in many cases, which caused errors after the triangulation as well (Figure 1). After this step the volume of this digital model were calculated. 


\section{Results}

Based on the wrap, the volume was calculated by the software. As a result, a continuous surface created to the volume calculation. The volumetric values were correlated with the diameter of the trunk (Figure 2).

Trunk and height of trees are complex vegetative indices for identify tree biomass. Based on the physically parameters with the calculated volume of trees, middle polynomial correlations were detected. Between the perimeter of trunk and volume of trees was higher correlation $(\mathrm{r}=0.61)$ than height of tree and volume of tree $(\mathrm{r}=0.54)$. The measured parameters are in Table 1.

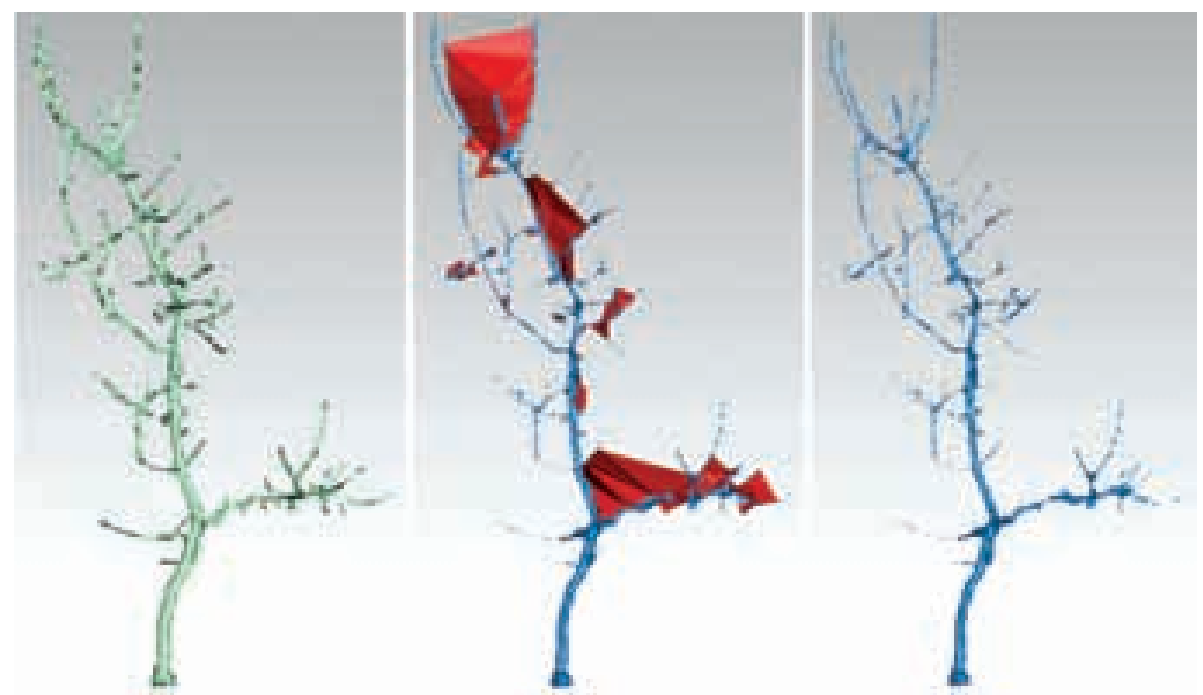

Figure 1. Steps of point cloud processing in Geomagic Studio 12 software environment
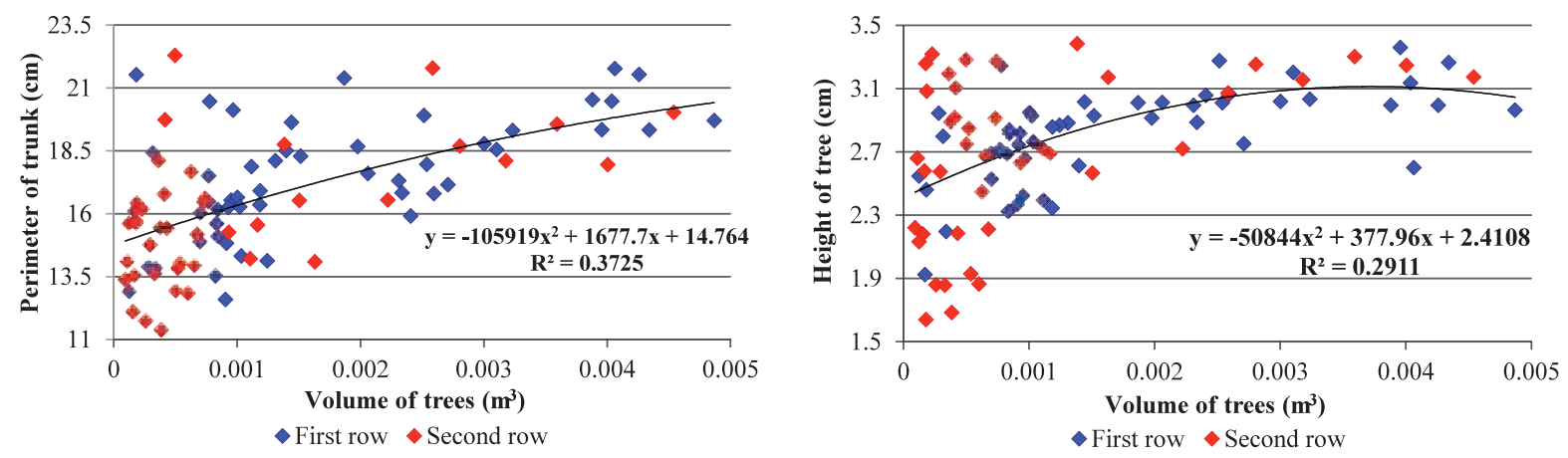

Figure 2. Correlation between trees volume and the investigated structural parameters

The values of calculated trees' volume are smaller than existing values. The reason of this difference is the automatically wrapping by the software.

Table 1. The used parameters from point cloud and wrap data

\begin{tabular}{|l|r|c|c|}
\hline & $\begin{array}{c}\text { Volume of tree } \\
\left(\mathrm{mm}^{3}\right)\end{array}$ & $\begin{array}{c}\text { Perimeter of } \\
\text { trunk }(\mathrm{cm})\end{array}$ & $\begin{array}{c}\text { Height of tree } \\
(\mathrm{m})\end{array}$ \\
\hline Mean & 1413968.24 & 16.76 & 2.76 \\
\hline Std. Deviation & 1267194.32 & 2.57 & 0.41 \\
\hline MIN & 93407.99 & 11.38 & 1.64 \\
\hline MAX & 4867506.78 & 22.30 & 3.38 \\
\hline
\end{tabular}

\section{Conclusions}

Based on evaluation of 3D laser scanner survey results the detection of certain quantitative and qualitative parameters becomes faster, however it will be necessary to refine the field survey results. However, to carry out further investigations (e.g. $\mathrm{CO}_{2}$ capture estimate) the calculated volume values of the software may also mean approximate baseline. Longer plan to clarify this results use with field survey and estimate the annual $\mathrm{CO}_{2}$ fixing in the intensive apple orchard in biomass with GIS.

\section{Acknowledgment}

The laser scanning was provided by the University of West-Hungary, Faculty of Geoinformatics. The authors thank Attila Váradi from Leica Geosystems Hungary Ltd. for his assistance in Leica software processing. This research was realized in the frames of TÁMOP 4.2.4. A/2-11-1-2012-0001 „National Excellence Program - Elaborating and operating an inland student and researcher personal support system". The project was subsidized by the European Union and cofinanced by the European Social Fund.

\section{References}

Belényesi M., Kristóf D., Skutai J. (2008): Távérzékelés a környezetgazdálkodásban. Elméleti jegyzet. Szent István Egyetem. Környezetgazdálkodási Intézet. Gödöllő. 78. 
Burai P. (2007): Távérzékelési módszerek összehasonlító elemzése mezőgazdasági területeken. Doktori (Phd) értekezés. Debrecen. 143 p. Führer E., Járó Z. (1989): Az éghajlat változékonyságának és feltételezett változásának hatása az erdőállományokra, az erdőgazdálkodásra. [In: Az éghajlat változékonysága és változása.] I. Környezetvédelmi és területfejlesztési Minisztérium. Országos Meteorológiai Szolgálat. 63-69.

Führer E., Járó Z., Márkus L. (1991): A magyarországi erdők szénmegkötő képessége és éghajlati hatások a hosszú termesztési idejü fák növekedésére. [In: Az éghajlat változékonysága és változása.] II. Környezetvédelmi és területfejlesztési Minisztérium. Országos Meteorológiai Szolgálat. 67-73.

Gyeviki M., Magyar L., Hrotkó K. (2011): Intenzív cseresznyeültetvény, mint mesterséges ökoszisztéma és biológiailag aktív felület értékelése $\mathrm{CO}_{2}$ megkötés és vízhasznosulás szempontjából. Műhelytanulmány. Corvinus Egyetem. Budapest. 28 p.

Gyeviki M., Steiner M., Juhász Á., Szabó V., Hrotkó K. (2012): Intenzív cseresznyeültetvény, mint mesterséges ökoszisztéma és biológiailag aktív felület értékelése $\mathrm{CO}_{2}$ megkötés és vízhasznosulás szempontjából. [In: Fenntartható fejlődés, élhető régió, élhető települési táj.] Budapesti Corvinus Egyetem. Budapest. 45-65.

Heritage, G. L., Large, A. R. G. (2009): Laser Scanning for the Environmental Sciences. Blackwell Publishing Ltd. Chichester, West Sussex, UK. 278 p.

Kiss M., Tanács E., Keveiné Bárány I. (2011): Karsztos erdők szénmegkötésével kapcsolatos számítások egy erdőrezervátum adatai alapján. Karsztfejlődés 16: 157-166.
Lóki J. (1996): Távérzékelés. Kossuth Egyetemi Kiadó. Debrecen, $113 \mathrm{p}$.

Molenaar M. (1993): Remote Sensing as an Earth Viewing system. [In: Buiten, H. J., Clevers, J. G. P. W. (ed.): Land Observation by Remote Sensing - Theory and Applications.] Overseas Publishers Association, Amsterdam. 27-36 p.

Huang, P., Pretzsch, H. (2010): Using terrestrial laser scanner for estimating leaf areas of individual trees in a conifer forest. Trees. 24 (4): 609-619.

Short N. M. (2011): The Remote Sensing Tutorial. Online: NASA. (http://rst.gsfc.nasa.gov/Front/overview.html/)

Stephens, P., Watt, P., Loubser, D., Haywood, A., Kimberly, M. (2007): Estimation of carbon stocks in New Zealand planted forests using airborne scanning lidar. International Archives of Photogrammetry, Remote Sensing and Spatial Information Sciences, 36 (Part 3/W52), 389-394.

Radó D. (2001): A növényzet szerepe a környezetvédelemben. Zöld Érdek Alapítvány és a Levegö Munkacsoport. Budapest. $148 \mathrm{p}$.

Seidel, D., Leuschner, C., Müller, A., Krause, B. (2011): Crown plasticity in mixed forests - Quantifying asymmetry as a measure of competition using terrestrial laser scanning. Forest Ecology and Management. 261. (11): 2123-2132.

Vosselman G., Hans-Gerd M. (2010): Airborne and Terrestrial Laser Scanning. Whittles Publishing, CRC Press. 336 p. 